\title{
Mediastinal osteosarcoma metastasis causing right heart failure due to pulmonary trunk compression
}

\author{
Claudiu Nistor, ${ }^{1}$ Daniel P Fudulu, ${ }^{2}$ Daniel Pantile, ${ }^{1}$ Teodor Horvat ${ }^{3}$
}

1‘Dr. Carol Davila' Central Emergency University Military Hospital, Bucharest, Romania ${ }^{2}$ University of Bristol, Bristol, UK

${ }^{3}$ Institute of Oncology "Prof. Dr. Alexandru Trestioreanu", Bucharest, Romania

\section{Correspondence to} Daniel P Fudulu, danielfudulu@gmail.com

Accepted 5 October 2016

\section{CrossMark}

To cite: Nistor $C$, Fudulu DP, Pantile D, et al. BMJ Case Rep Published online: [please include Day Month Year] doi:10.1136/ bcr-2016-217431

\section{DESCRIPTION}

We present the case of a woman aged 27 years with a background of operated femoral osteosarcoma 9 months ago. She was transferred to our hospital with worsening shortness of breath and signs of decompensated heart failure, haemodynamic instability and suspicion of pericardial effusion. Her transthoracic echocardiogram ruled out a pericardial collection but revealed severe tricuspid regurgitation and right ventricular dilation (figure 1A). A chest CT scan demonstrated an anterior mediastinal mass causing pulmonary trunk compression with subsequent right heart strain and bilateral congestive pleural effusions (figure 1B,C). Haemodynamic instability dictated urgent palliative surgical debulking that was performed under local anaesthesia and sedation via an anterior mediastinotomy approach, due to anaesthetic concerns (figure 2A). This resulted in decompression of the pulmonary trunk and improvement in the patient condition to allow further oncological treatment. The subsequent histopathological examination confirmed osteosarcoma metastasis.
Following oncological medical treatment, the patient was transferred several months later to another unit where surgery with curative intent was attempted, but unfortunately, the patient died intraoperatively.

\section{Learning points}

- Anterior mediastinal tumours can cause haemodynamic instability by compression of the pulmonary trunk resulting in right heart strain.

- Patients presenting with haemodynamic compromise can benefit from anterior mediastinotomy and debulking under local anaesthetic and sedation.

\section{Competing interests None declared.}

Provenance and peer review Not commissioned; externally pee reviewed.

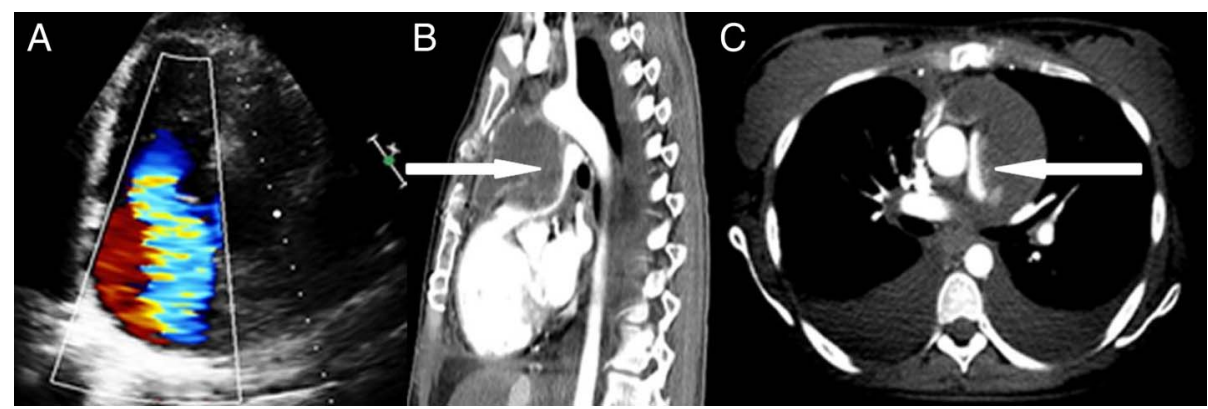

Figure 1 (A) Transthoracic echocardiographic findings: right ventricular and atrial dilation and functional severe tricuspid regurgitation; $C T$ scan (B) sagittal plane reconstruction and (C) transversal plane, with the arrow pointing to the compression of the pulmonary trunk by the mediastinal metastasis of osteosarcoma.

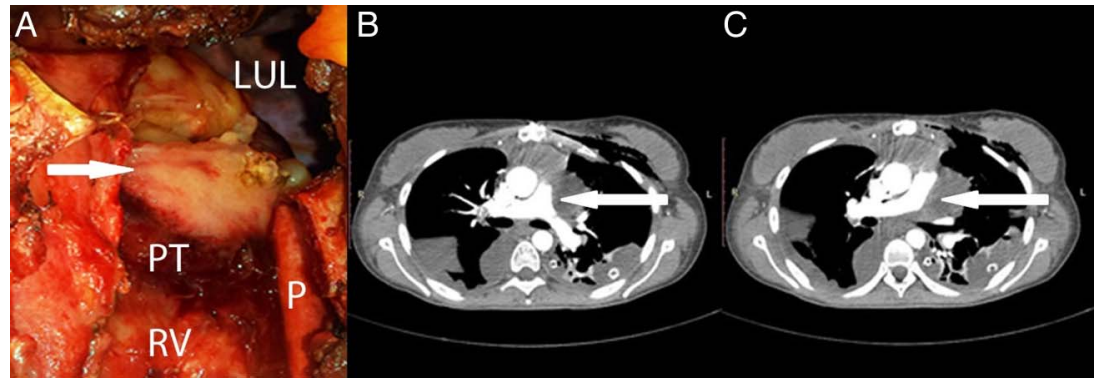

Figure 2 (A) Intraoperative aspect (left anterior mediastinotomy): mediastinal osteosarcoma metastasis with pulmonary trunk compression. LUL, left upper lobe; PT, pulmonary trunk; RV, right ventricle; $\mathrm{P}$, pericardium; postoperative $\mathrm{CT}$ scan (B and $\mathrm{C}$ ) demonstrating decompression of the pulmonary trunk. 
Copyright 2016 BMJ Publishing Group. All rights reserved. For permission to reuse any of this content visit http://group.bmj.com/group/rights-licensing/permissions.

BMJ Case Report Fellows may re-use this article for personal use and teaching without any further permission.

Become a Fellow of BMJ Case Reports today and you can:

- Submit as many cases as you like

- Enjoy fast sympathetic peer review and rapid publication of accepted articles

- Access all the published articles

- Re-use any of the published material for personal use and teaching without further permission

For information on Institutional Fellowships contact consortiasales@bmjgroup.com

Visit casereports.bmj.com for more articles like this and to become a Fellow 